\title{
The ameliorating effect of silymarin against vancomycin- induced apoptosis and inflammation in rat liver
}

\author{
Sevda GÜZEL ${ }^{1}$ * (D), Zuhal UÇKUN ŞAHINOĞULLARI ${ }^{2}$ (D), Necmiye CANACANKATAN ${ }^{3}$ (D), \\ Şerife Efsun ANTMEN 4 (D), Deniz KİBAR 5 (D), Gülsen BAYRAK ${ }^{5}$ (D)
}

1 Department of Pharmacognosy, Faculty of Pharmacy, Mersin University, Mersin, Turkey.

2 Department of Pharmaceutical Toxicology, Faculty of Pharmacy, Mersin University, Mersin, Turkey.

3 Department of Biochemistry, Faculty of Pharmacy, Mersin University, Mersin, Turkey.

4 Vocational School of Medical Services, Mersin University, Mersin, Turkey.

5 Department of Histology and Embryology, Faculty of Medicine, Mersin University, Mersin, Turkey.

* Corresponding Author. E-mail: guzelsevda@mersin.edu.tr (S.G.); Tel. +90-553-126 3692.

Received: 01 January 2019 / Revised: 18 February 2019 / Accepted: 24 February 2019

\begin{abstract}
Silymarin (SL), a flavonolignan complex isolated from seeds of Silybum marianum (Asteraceae), is known for its hepatoprotective, anti-apoptotic, anti-inflammatory, and antioxidant activities. A glycopeptide antibiotic, Vancomycin (VA) which is used for the treatment of serious infections caused by multi-resistant Gram-positive microorganisms has been clinically used for a long time. The aim of the present study was to evaluate potential therapeutic efficiency of SL against VA-induced apoptosis and inflammation using apoptotic (caspase-3, -8, and, -9 enzyme activities) and inflammatory (Tumor necrosis factor-alpha (TNF-a)) markers, and histopathological examinations in rat liver. A total of 49 male Wistar albino rats was divided into 7 groups including control (saline, intraperitoneally (i.p.)), Dimethyl sulfoxide (i.p.), VA (400 mg/kg/day, i.p.), SL100 (100 mg/kg/day, i.p.), VA+SL50 (50 $\mathrm{mg} / \mathrm{kg} /$ day, i.p.), VA+SL100 (100 mg/kg/day, i.p.), and VA+SL200 (200 mg/kg/day, i.p.). SL was administered once a daily for 8 days. One day after the first treatment of SL, VA administration was started and continued for 7 days. Hepatic TNF-a levels were evaluated by ELISA and hepatic caspase activities were evaluated according to the colorimetric method. Significantly increased caspase activities were determined in VA group compared to control group $(\mathrm{P}<0.05)$. However, significantly reduced caspase activities were determined in VA+SL200 group when compared to VA group $(\mathrm{P}<0.05)$. TNF-a level in VA group was found to be statistically higher than control group $(\mathrm{P}<0.05)$. TNF-a levels of SL100, VA+SL (50, 100, and 200) groups were significantly lower than VA group $(\mathrm{P}<0.05)$. VA+SL200 group was found to be the most effective group according to reducing caspase activities and TNF-a level.
\end{abstract}

KEYWORDS: Caspase; hepatoprotective; histopathology; silymarin; TNF-a.

\section{INTRODUCTION}

The liver is a vital organ that plays a key role in the maintenance of homeostasis [1,2]. It is responsible from multiple metabolic functions and physiological processes including generation of energy, production of bile, storage of vitamins, and metabolisms of carbohydrates, lipids, proteins [1], drugs, and toxic chemicals [3]. After completing intestinal absorption, the blood which becomes rich in nutrients and xenobiotics is transported to the liver with multiple toxic substances such as drugs, toxins, and pharmaceuticals [1]. Because of detoxifying several chemicals, toxic substances, and microbiological agents [2] liver is the primary target organ for approximately all toxic substances [3]. Therefore, the liver is susceptible to toxicity and damage [1].

Due to low cost, availability, effectiveness and lesser side effects, medicinal plants and their products are important sources of medicine worldwide [4]. Natural compounds with antioxidant and antiinflammatory properties could prevent the adverse effects of toxic substances by scavenging free radicals and modulating inflammatory response [3]. Flavonoids, kind of the natural compound with polyphenolic structure, are isolated from various plants and have several pharmacological properties including antioxidant, anti-inflammatory, anticancer, wound healing, and neuro-protective [5].

Silymarin (SL) is a standardized mixture of flavonolignans including silibinin (the major one), isosilibinin, silydianin, and silychristin; and isolated from the seeds and fruits of Silybum marianum [L.] Gaertner (Asteraceae) which is commonly known as milk thistle or St. Mary's thistle $[1,2,6]$ and has been

How to cite this article: Güzel S, Uçkun Şahinoğulları Z, Canacankatan N, Antmen SE, Kibar D, Bayrak G. The ameliorating effect of silymarin against vancomycin-induced apoptosis and inflammation in rat liver. J Res Pharm. 2019; 23(4): 719-728. 
traditionally used for protecting liver health since ancient times [7]. SL has been widely used for the treatment of liver and gall bladder disorders, and also has beneficial effects on different organ illnesses and broad range of cancers [8]. Hepatoprotective [3], anti-apoptotic, strong antioxidant [8], anti-inflammatory, immunomodulatory [8, 9], membrane-stabilizing [7], and antiviral properties [9, 10] of SL have been reported in previous studies. Experimental and clinical studies also indicated that antioxidant activity of SL reduces inflammatory reaction, promotes hepatocyte regeneration, and inhibits fibrogenesis [7]. Vancomycin (VA), which is a glycopeptide antibiotic, has been used for the treatment of severe infections caused by multiresistant Gram-positive microorganisms including methicillin-resistant Staphylococcus aureus, methicillinresistant coagulase-negative staphylococci and Enterococcus faecium. However, VA is associated with some adverse effects including nephrotoxicity [11]. In previous studies, the protective effect of SL was demonstrated against drug/chemical-induced oxidative stress, inflammation and apoptosis in the liver tissues [12-14], while there is no study on hepatoprotective effects of SL against VA-induced apoptosis and inflammation in the literature. Therefore, the subject of the study was to evaluate potential protective effects of SL against VAinduced apoptosis and inflammation using apoptotic (caspase-3, -8, and -9 enzyme activities) and inflammatory (Tumor necrosis factor-alpha (TNF-a)) markers, and histopathological parameters (sinusoidal dilatation, vacuolization, nuclear pleomorphism, necrosis, inflammation, pyknosis, capsule thickening, and fibrosis) in rat liver.

\section{RESULTS}

\subsection{Determination of caspase- $3,-8$, and -9 enzyme activities}

Results of hepatic caspase enzyme activity are presented in Figure 1. Significantly increased caspase-3, -8 , and -9 activities were determined in VA, VA+SL50, and VA+SL100 groups when compared to control group $(\mathrm{P}<0.05)$. Statistically reduced caspase- $3,-8$, and -9 activities were determined in VA+SL200 group when compared to VA group $(\mathrm{P}<0.05)$. Caspase-3, -8 , and -9 activities in SL100, VA+SL50, and VA+SL100 groups were found to be statistically higher than VA+SL200 group $(\mathrm{P}<0.05)$. There were no significant differences between VA, VA+SL50, and VA+SL100 groups $(\mathrm{P}>0.05)$.

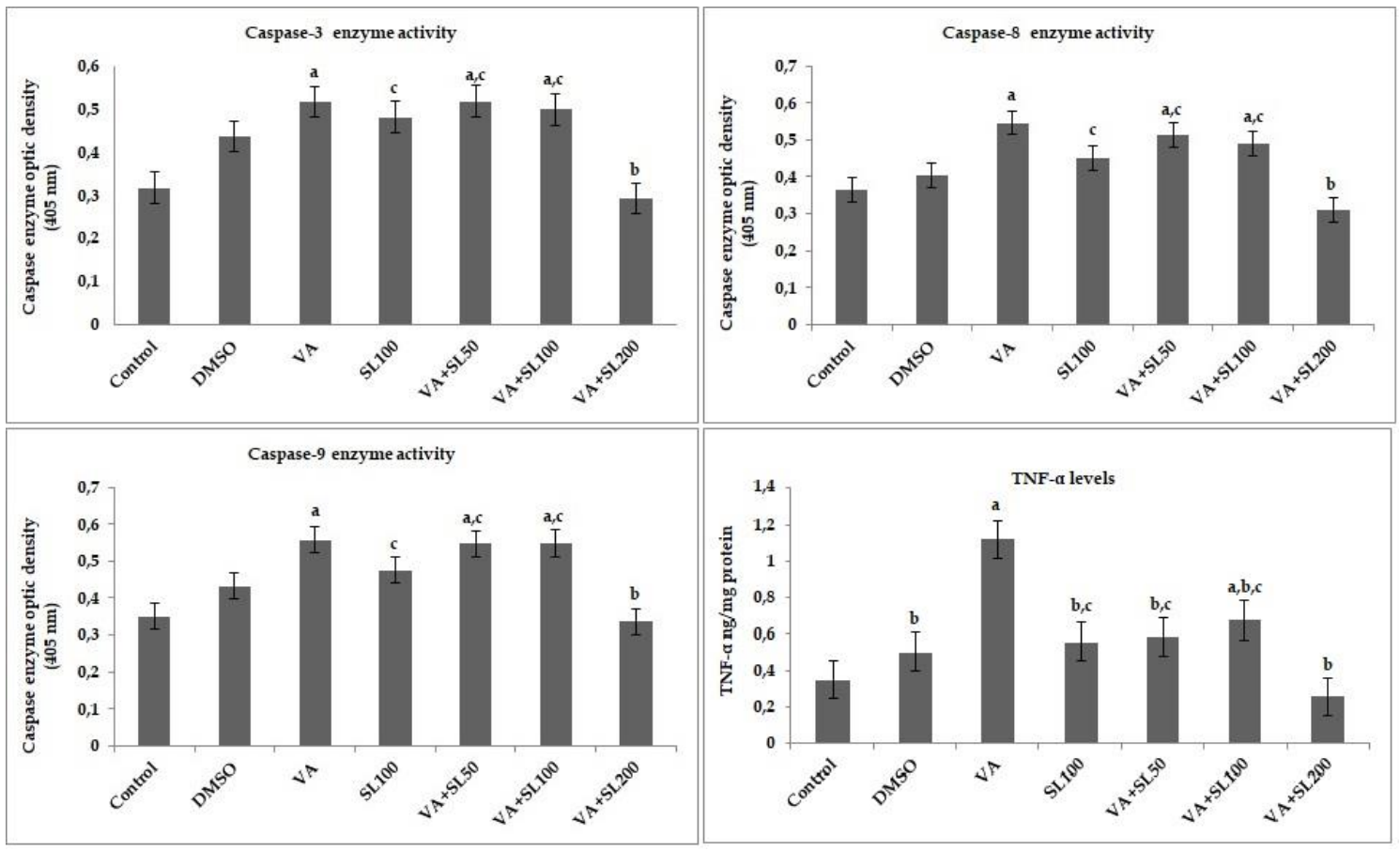

Figure 1. Hepatic caspase-3, -8 , and, -9 enzyme activities and TNF-a levels in studied groups. (Values are presented as mean $\pm \mathrm{SD}$. $\mathrm{P}<0.05$ was considered to be significant. a Significantly different from control group. b

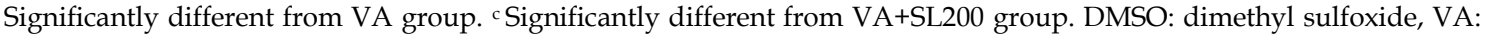
vancomycin, SL: silymarin, TNF-a: Tumor necrosis factor-alpha). 


\subsection{Determination of hepatic TNF-a level}

Hepatic TNF-a levels of studied groups are provided in Figure 1. The highest TNF- $\alpha$ level was observed in VA group, while the lowest TNF-a level was observed in VA+SL200 group. When compared to control group, significantly increased TNF- $\alpha$ levels were determined in VA and VA+SL100 groups $(\mathrm{P}<0.05)$. TNF- $a$ levels in DMSO, SL100, VA+SL $(50,100$, and 200) groups were statistically different than VA group $(\mathrm{P}<0.05)$. Significantly different TNF-a levels were observed in SL100, VA+SL (50 and 100) groups when compared to $\mathrm{VA}+\mathrm{SL} 200$ group $(\mathrm{P}<0.05)$. Comparison of VA, VA+SL $(50,100$, and 200$)$ groups indicated that reduced TNFa levels were determined in VA+SL $(50,100$, and 200) groups.

\subsection{Histopathological study}

Histopathological evaluation of liver tissues was examined using various parameters including sinusoidal dilatation, vacuolization, nuclear pleomorphism, necrosis, inflammation, pyknosis, capsule thickening, and fibrosis (Table 1 and Figures 2-5). Sinusoidal dilatation, vacuolization, nuclear pleomorphism, and pyknosis were not observed in any of the studied groups. Comparison of all studied groups between each other indicated that mild necrosis and mild inflammation in VA and VA+SL50 groups; mild capsule thickening in VA, VA+SL50, and VA+SL200 groups; and mild fibrosis in DMSO, VA, and VA+SL200 groups were observed. There were no meaningful histopathological damage in control, SL100, and VA+SL100 groups. According to the histopathological results, among the VA applied groups (VA, VA+SL (50, 100, and 200)), VA+SL100 group showed the best healing and VA+SL200 group followed it.

Table 1. Scores of histopathological changes induced by VA in rat liver tissues.

\begin{tabular}{lccccccc}
\hline $\begin{array}{l}\text { Histopathological } \\
\text { parameters }\end{array}$ & Control & DMSO & VA & SL100 & VA+SL50 & VA+SL100 & VA+SL200 \\
\cline { 2 - 7 } & - & - & - & - & - & - & - \\
Sinusoidal dilatation & - & - & - & - & - & - & - \\
Vacuolization & - & - & - & - & - & - & - \\
Nuclear pleomorphism & - & - & + & - & + & - & - \\
Necrosis & - & - & + & - & + & - & - \\
Inflammation & - & - & - & - & - & - & - \\
Pyknosis & - & - & + & - & + & - & + \\
Capsule thickening & - & + & + & - & - & - & + \\
Fibrosis & - & & & & & & - \\
\hline
\end{tabular}

+++: severe; ++: moderate; +: mild; -: none.

DMSO: Dimethyl sulfoxide, VA: vancomycin, SL: silymarin, VA+SL: vancomycin and silymarin administered group.

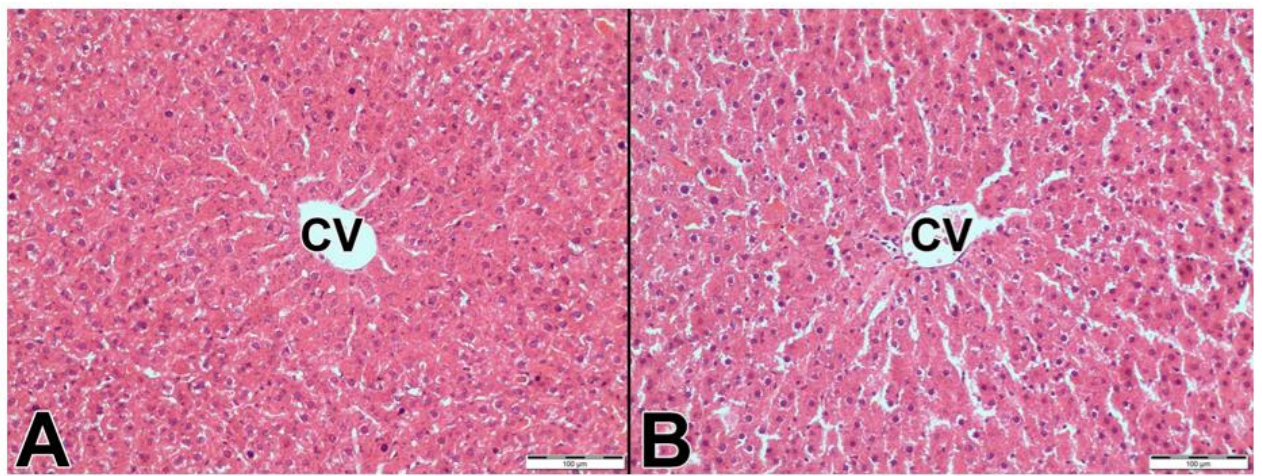

Figure 2. Representative photomicrographs of liver sections stained with H\&E. Control group (A), and SL group (B). (Central vein (CV). A and B X100). 


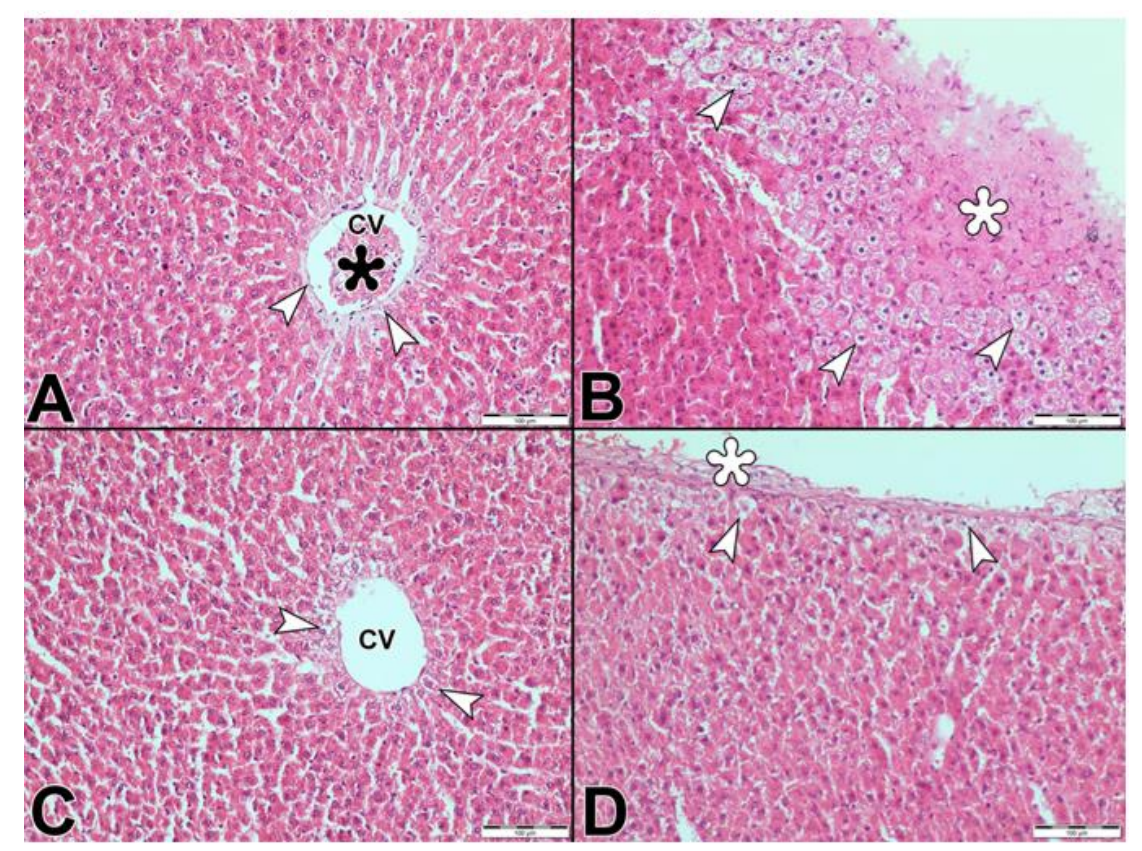

Figure 3. Representative photomicrographs of liver sections stained with H\&E. VA group (A, B), and VA+SL50 (C, D). (Central vein (CV), necrotic cells with cytoplasmic vacuoles (white arrowhead), cell debris in the lumen of the vein (black asterisk), capsule thickening (white asterisk). A, B, C, D X100).

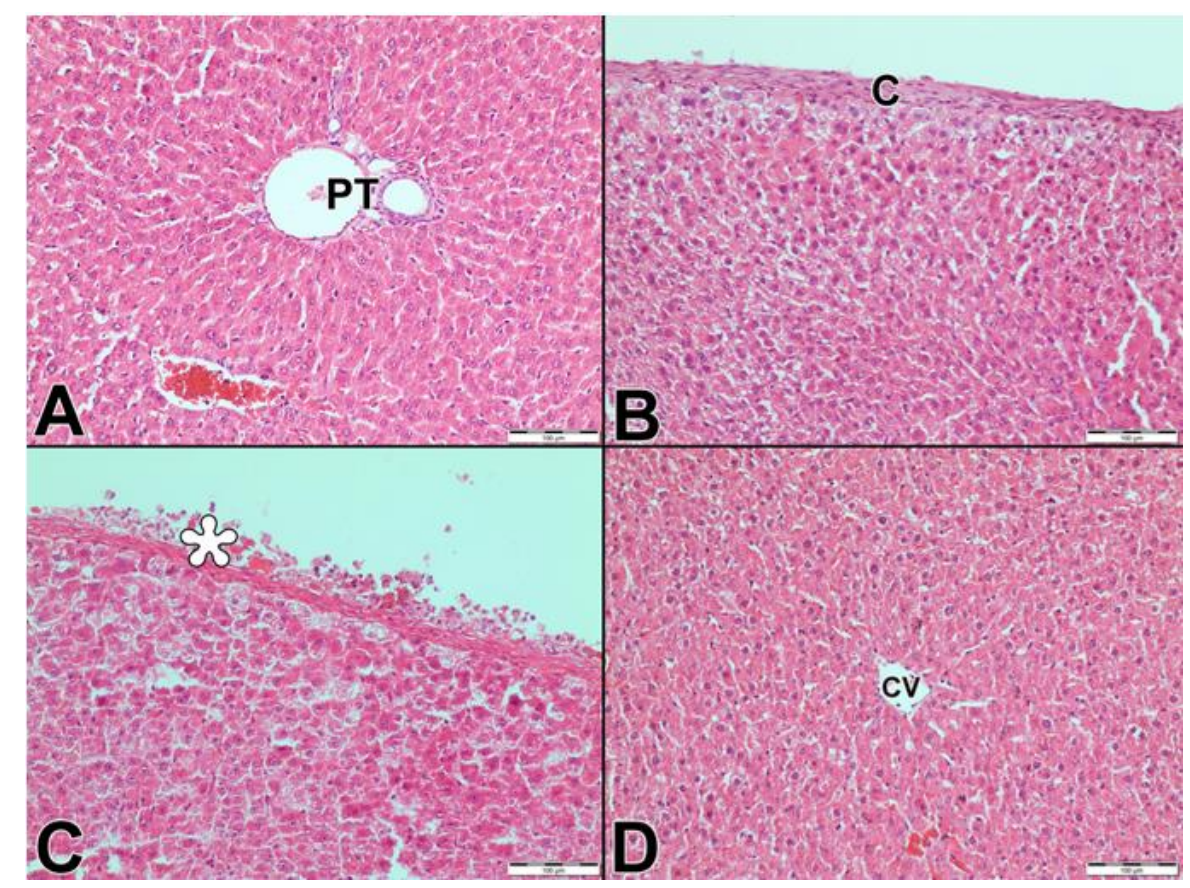

Figure 4. Representative photomicrographs of liver sections stained with H\&E. VA+SL100 (A, B), VA+SL200 (C), DMSO group (D). (Portal triad (PT), capsule (C), capsule thickening (white asterisk), central vein (CV). A, B, C, D X100). 


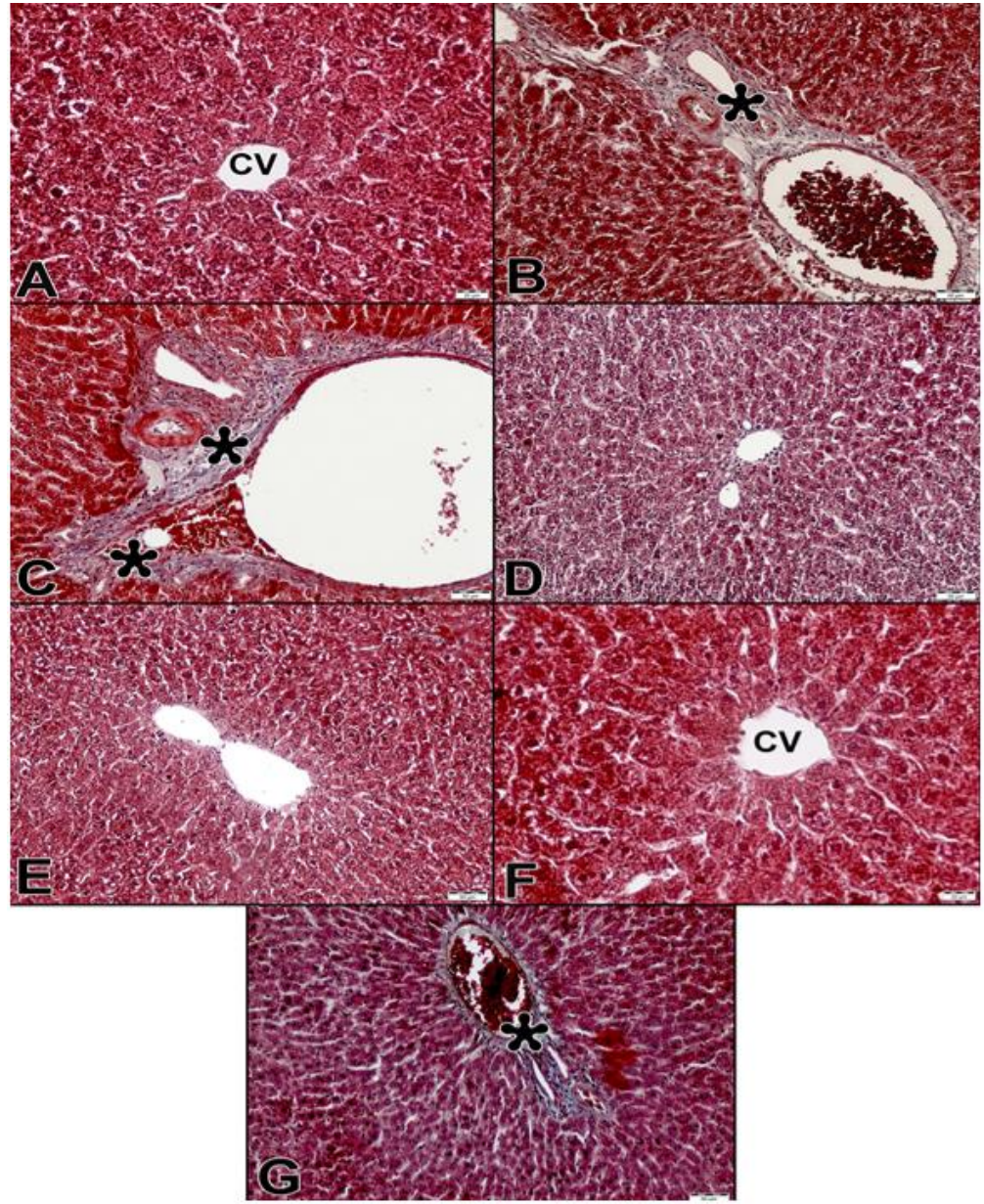

Figure 5. Representative photomicrographs of liver sections stained with Masson's Trichrome. Control group (A), DMSO group (B), VA group (C), SL group (D), VA+SL50 group (E), VA+SL100 group (F), VA+SL200 group (G). (Central vein (CV), fibrosis (asterisk). A and F X200; B, C, D, F, G X100).

\section{DISCUSSION}

Potential protective effects of SL with different doses $(50,100$, and $200 \mathrm{mg} / \mathrm{kg} /$ day) were examined against VA-induced apoptosis and inflammation using apoptotic (caspase-3, -8 , and -9 enzyme activities) and inflammatory (TNF- $\alpha$ ) markers, and histopathological parameters including sinusoidal dilatation, vacuolization, nuclear pleomorphism, necrosis, inflammation, pyknosis, capsule thickening, and fibrosis in rat liver.

The combination of many factors including oxidative stress, fatty-acid metabolic disturbance, abnormal cytokine production, and insulin resistance leads to cause hepatocyte injury via direct oxidative injury, inflammation, and/or TNF- $\alpha$ induced apoptosis [7]. Apoptosis which is a normal cell-death process driven by various stimuli [15] plays a crucial role in liver injuries [16]. Apoptosis has two main pathways including the extrinsic and intrinsic pathways [6]. Oxidative stress can induce apoptosis via the mitochondrial/intrinsic and/or the death receptor/extrinsic pathways [17]. Cell death receptors and their ligands like TNF receptors usually associate with the extrinsic pathway. Caspase family plays a crucial role in regulation of various apoptotic responses [6]. The intrinsic pathway is characterized by the efflux of cytochrome $C$ from mitochondria to the cytosol; where the initiator caspase-9, a key component in the execution stage of apoptosis, is activated and this triggers the caspase- 3 and caspase-7 activation [6, 18]. Caspase- 3 can be characterized as a key mediator of apoptosis in mammalian due to initiating apoptotic process via activating other caspase enzymes [18]. Moreover, increased caspase-8 and -9 activities stimulate extrinsic and intrinsic pathways of apoptosis [19]. High doses of VA have been generally associated with nephrotoxicity which is the main sideeffects of it [20]. Besides nephrotoxicity, other VA toxicities such as red man syndrome, ototoxicity, neutropenia, phlebitis, fever, thrombocytopenia, linear IgA bullous dermatosis, lacrimation, toxic epidermal necrolysis, necrotising cutaneous vasculitis, and Stevens-Johnson syndrome have been reported previously 
[21]. Elimination of VA is almost renal [21, 22], while nearly 5 to $8.5 \%$ of VA clearance is extra-renal, probably by hepatic conjugation, leading to VA crystalline degeneration products [21]. According to literature, VA has side effects on liver which limit the therapeutic use of it in patients with impaired liver function. However, there are a few studies on the mechanism of VA-induced hepatotoxicity and limited data is known about the side effects on hepatic functions. Sahin et al. investigated effects of VA on rat liver at the administration dose of $200 \mathrm{mg} / \mathrm{kg}$ VA (i.p.) twice daily for 7 days and they found that VA induced oxidative stress and this resulted in hepatotoxicity [22]. Previous studies on VA-induced nephrotoxicity indicated that VA has a stimulating role in free radical production and oxidative phosphorylation. After VA administration, free radical overproduction causes some changes including protein denaturation, membrane lipids peroxidation, DNA damage, cellular injury, and oxidation of carbohydrates and nucleic acids [18]. SL has membrane-stabilizing and antioxidant activities and reduces inflammatory reaction, inhibits fibrogenesis, promotes hepatocyte regeneration via stimulating RNA polymerase enzyme in the nucleus of liver cells [23]. SL stimulates RNA and protein synthesis leading to faster regeneration and repair, after liver injury [12]. Furthermore, the ability of SL to protect against oxidative stress-induced hepatocellular damage is especially involved in its free radical scavenging properties [23]. Besides antioxidant and free radical scavenging properties, other major hepatoprotective mechanisms of SL were reported as anti-inflammatory, immunomodulating, and antifibrotic activities [3]. Because of antioxidant and radical scavenging properties, SL has also cytoprotective effect [24]. In the current study, increased caspase-3, -8 and -9 enzyme activities were observed in VA, VA+SL50, and $\mathrm{VA}+\mathrm{SL100}$ groups when compared to control group $(\mathrm{P}<0.05)$. However, reduced caspase-3, -8 and -9 enzyme activities were determined in VA+SL200 group when compared to VA group $(\mathrm{P}<0.05)$. Due to their polyphenolic structure, flavonoids can act as pro- and/or antioxidant; however, these effects depend on dose and type of cell [25]. Anticancer activity of SL was also reported against several cancer types [1]. Some studies reported that SL suppresses caspase activation [9] and prevents apoptotic cell development [2, 24]. Our results suggested that pre-treatment of high dose $(200 \mathrm{mg} / \mathrm{kg} /$ day $)$ of SL was significantly reduced caspase activities against VA-induced hepatotoxicity and concentration of SL is important for balancing oxidant-antioxidant status in liver tissues. In the present study, dose of $100 \mathrm{mg} / \mathrm{kg} /$ day SL which is mostly preferred dose in experimental studies [26] caused increasing levels of caspase $-3,-8$ and -9 activities in SL 100 group. Dose depended pro- and/or antioxidant properties of these substance might also explain why elevated caspase -3, -8 and -9 activities were observed in SL100 group.

The cytokines which actively play key roles in numerous physiological phenomena including inflammation, tissue repair, immune response, cell growth and cell differentiation are low molecular weight regulatory proteins $[2,18]$. During the inflammation, activated inflammatory cells released increasing amounts of nitric oxide and cytokines, like interleukins IL-1 $\beta$, IL-6, and TNF- $\alpha$ [27]. In the liver, TNF- $\alpha$ is associated with pathophysiology of liver diseases like non-alcoholic fatty liver disease, viral hepatitis, and alcoholic steatohepatitis. The over-production of reactive oxygen species leads to over-expression of TNF- $\alpha$ in hepatocytes, kupffer cells and adipose tissue [16]. Following exposure to hepatotoxic chemicals, the TNF- $\alpha$ expression increases in acute liver diseases [3], therefore, TNF- $\alpha$ is a widely chosen hepatotoxic substance which is used for experimentally induction of liver damage [2]. In the present study, significantly increased TNF-a level was observed in VA group, when compared to control group $(\mathrm{P}<0.05)$. Comparison of VA+SL $(50,100$, and 200) groups to VA group indicated that reduced TNF-a levels were observed in all tested VA+SL $(50,100$, and 200) groups, while the lowest TNF-a level was observed in VA+SL200 group. According to the literature data SL has nuclear expression regulatory capacity [8]. Anti-inflammatory and cytoprotective effects of SL occur via TNF-a reduction [24] and SL also blocked TNF-induced cytotoxicity [28]. SL protects the liver against hepatotoxin-induced liver damage via blocking activation of intrahepatic nuclear factor kappa B and consequently inhibiting intrahepatic TNF- $\alpha$ expression [13]. In vitro and in vivo studies indicated that SL modulates production of TNF- $\alpha$ and inflammation. Additionally, SL binds to hepatocellular receptors and does not allow toxins to bind these sites [12].

In the literature, a few studies were reported on VA-induced hepatotoxicity and side effects on hepatic functions [22]. In the present study, we examined several histopathological parameters including sinusoidal dilatation, vacuolization, nuclear pleomorphism, necrosis, inflammation, pyknosis, capsule thickening, and fibrosis in liver tissues after VA administration. Results showed that mild necrosis, inflammation, capsule thickening, and fibrosis were observed in VA group and VA caused hepatic injury. Comparison of histopathological results in VA+SL $(50,100$, and 200) groups indicated that pre-treatment of SL was led to cause different healing ratios in all VA+SL $(50,100$, and 200) groups. None of the screened parameters were detected at dose of $100 \mathrm{mg} / \mathrm{kg} /$ day in both SL100 and VA+SL100 groups. 
In previous studies, hepatoprotective effects of SL have been reported against various drugs/toxins including acetaminophen, carbon tetrachloride, D-galactosamine [7], ethanol [29], fumonisin B1 [13], cisplatin [23], isotretinoin [30], doxorubicin [12], and Amanita phalloides toxin [7], while this is the first study on the hepatoprotective effect of SL against VA-induced apoptosis and inflammation in rats.

\section{CONCLUSION}

After VA application in VA group, significantly increased TNF- $\alpha$ levels and caspase-3, -8 and -9 enzyme activities were observed in liver tissues. Pre-treatment of SL was significantly reduced the elevated TNF-a levels and caspase-3, -8 , and -9 enzyme activities, and these results were supported by histopathological evidence. The current study indicates that pre-treatment of SL can attenuate hepatic injury in rats treated with VA possibly by reducing the levels of the apoptotic (caspase- $3,-8$ and, -9 enzyme activities) and inflammatory (TNF-a) markers. As a conclusion, SL appears to have the potential as a hepatoprotective agent against VAinduced apoptosis and inflammation.

\section{MATERIALS AND METHODS}

\subsection{Chemicals}

Vancomycin hydrochloride (Vancotek flacon 1.0 g) was purchased from Kocak Farma (İstanbul, Turkey). Silymarin and Dimethyl sulfoxide (DMSO) were purchased from Sigma-Aldrich Chemistry (St. Louis, MO, USA). Freshly prepared chemicals and solutions were used for the experiments.

\subsection{Experimental design of the study}

The experimental protocol was approved by the Animal Experimental Local Ethics Committee of the Mersin University (Reg. No. 2016/21) and the animals were obtained from the Laboratory of the Animal Production Unit of the Mersin University, Mersin, Turkey. A total of 49, healthy male Wistar albino rats weighing 180 to $250 \mathrm{~g}$, was used for the study. The individually housed animals were kept in cages under standard conditions (light/dark cycle of $12 \mathrm{~h} / 12 \mathrm{~h}$ with $55 \pm 8 \%$ humidity, at $25^{\circ} \mathrm{C} \pm 2^{\circ} \mathrm{C}$ ) and were fed a standard pellet diet and water ad libitum during the study. The animals were randomly divided into seven groups comprising seven animals in each group. Doses of SL $[8,26,31]$ and VA $[32,33]$ were determined due to the previous studies. During the experiments, SL was dissolved in DMSO and VA was dissolved in Saline $(0.9 \% \mathrm{NaCl})$. The experimental design of the study is detailed in Table 2.

Table 2. Experimental design of the groups $(N=49)$.

\begin{tabular}{|c|c|c|}
\hline Group $^{a}$ & Group code & Application type \\
\hline Group 1 & Control & $\begin{array}{l}\text { Saline }(0.9 \% \mathrm{NaCl}) \text { was administered intraperitoneally (i.p.) at a dose of } 2 \\
\text { ml once daily throughout } 8 \text { days }\end{array}$ \\
\hline Group 2 & DMSO & $\begin{array}{l}\text { DMSO was administered at a dose of } 0.5 \mathrm{ml} \text { i.p. once daily throughout } 8 \\
\text { days }\end{array}$ \\
\hline Group 3 & VA & $\begin{array}{l}\text { VA was administered at a dose of } 400 \mathrm{mg} / \mathrm{kg} \text { body weight i.p. once daily } \\
\text { throughout } 7 \text { days at an interval of } 24 \mathrm{~h}\end{array}$ \\
\hline Group 4 & SL100 & $\begin{array}{l}\text { SL dissolved in DMSO was administered at a dose of } 100 \mathrm{mg} / \mathrm{kg} \text { body } \\
\text { weight i.p. once daily throughout } 8 \text { days }\end{array}$ \\
\hline Group 5b & $\mathrm{VA}+\mathrm{SL} 50$ & $\begin{array}{l}\text { SL was administered at a dose of } 50 \mathrm{mg} / \mathrm{kg} \text { body weight i.p. once daily } \\
\text { throughout } 8 \text { days. One day after the first treatment of SL, VA } \\
\text { administration ( } 400 \mathrm{mg} / \mathrm{kg} \text { body weight/day) was started and continued } \\
\text { for } 7 \text { days }\end{array}$ \\
\hline Group 6b & VA+SL100 & $\begin{array}{l}\text { SL was administered at a dose of } 100 \mathrm{mg} / \mathrm{kg} \text { body weight i.p. once daily } \\
\text { throughout } 8 \text { days. One day after the first treatment of SL, VA } \\
\text { administration ( } 400 \mathrm{mg} / \mathrm{kg} \text { body weight/day) was started and continued } \\
\text { for } 7 \text { days }\end{array}$ \\
\hline Group 7b & VA+SL200 & $\begin{array}{l}\text { SL was administered at a dose of } 200 \mathrm{mg} / \mathrm{kg} \text { body weight i.p. once daily } \\
\text { throughout } 8 \text { days. One day after the first treatment of SL, VA } \\
\text { administration ( } 400 \mathrm{mg} / \mathrm{kg} \text { body weight/day) was started and continued } \\
\text { for } 7 \text { days }\end{array}$ \\
\hline
\end{tabular}




\subsection{Anesthesia}

Xylazine hydrochloride and ketamine hydrochloride were used as anesthetics and injected i.p. at doses of $10 \mathrm{mg} / \mathrm{kg}$ and $30 \mathrm{mg} / \mathrm{kg}$, respectively [34]

\subsection{Collection of organs}

On 9th day, all the rats were sacrificed after liver tissue of each rat was harvested under anesthesia. Liver tissues were blotted free of adhering fluid, weighed and used for biochemical and histopathological studies. In ice-cold lysis buffer, the liver homogenates were prepared, and after centrifugation of the homogenates at $14000 \times \mathrm{g}$ at $4^{\circ} \mathrm{C}$ for $10 \mathrm{~min}$, the clear supernatants were obtained to use further analysis.

\subsection{Biochemical studies}

\subsubsection{Determination of caspase- $3,-8$, and, -9 enzyme activities}

Colorimetric Test Kit (BioVision Research Product, Mountain View, CA) method was used for evaluating the hepatic caspase enzyme activities. All enzyme activities were performed due to manufacturer's instructions. The method described in Lowry et al. was used for measuring the protein levels [35]. Briefly, 50 $\mathrm{mg}$ of protein was diluted in $50 \mathrm{~mL}$ of dilution buffer. Caspase- $3,-8$, and, -9 colorimetric assay kits which based on spectrophotometric measurement of the chromophore p-nitroanilide (pNA) after cleavage from the labeled substrate were used. Asp-Glu-Val-Asp (DEVD)-pNA, Ile-Glu-Thr-Asp (IETD)-pNA and Leu-GluHis-Asp (LEHD)-pNA were used as caspase-3, -8, and, -9 enzyme substrates, respectively. pNA light emission was quantified at $405 \mathrm{~nm}$ wavelength using a microplate reader (Thermo Fisher Scientific, MA, USA).

\subsubsection{Determination of TNF-a level}

Levels of TNF-a in liver tissue were studied with a quantitative sandwich enzyme immunoassay (ELISA; BioVision Research Product, Mountain View, CA) according to the manufacturer's instructions. The results are given as $\mathrm{ng} / \mathrm{mg}$ protein.

\subsection{Histopathological study}

At the end of the experiments weighed livers were cut into $1 \mathrm{~cm}^{3}$ pieces and fixed for $48 \mathrm{~h}$ in neutral buffered formalin solution (10\%). Upon fixation, tissue samples were processed routinely, embedded in paraffin wax and cut at $5 \mu \mathrm{m}$ thick on a rotary microtome. Sections were mounted on glass slides, stained with hematoxylin and eosin (H\&E) and Masson's Trichrome. They were visualized under the light microscope (Olympus BX50, Olympus GmBH Tokyo, JAPAN) for histopathological evaluations. General morphology was analyzed from randomly chosen five fields per section by two blind observers and grading was done using a semiquantitative scale: (-) no meaningful histopathological damage; $(+)$ mild degree of damage; $(++)$ moderate degree of damage, and (+++) severe degree of damage. Grading was performed according to sinusoidal dilatation, vacuolization, nuclear pleomorphism, necrosis, inflammation, pyknosis, capsule thickening, and fibrosis.

\subsection{Statistical analyses}

The statistical analyzes were performed using SPSS 16 (IBM, New York, USA) software program. The data are represented as the mean \pm standard deviation (SD) and all data were statistically evaluated using Kruskal Wallis $\mathrm{H}$ and Mann Whitney U, and one-way analysis of variance (ANOVA) with Tukey's post hoc test. P values $<0.05$ were considered as statistically significant.

Acknowledgements: This study was supported with Project Number 2016-2-AP3-1906 by the Research Fund of Mersin University, Turkey.

Author contributions: Concept - S.G., Z.U.Ş., N.C.; Design - S.G., Z.U.Ş., N.C.; Supervision - S.G., Z.U.Ş., N.C.; Materials - S.G., Z.U.Ş., N.C., Ş.E.A., D.K., G.B.; Data Collection and/or Processing - S.G., Z.U.Ş., N.C. D.K.; Analysis and/or Interpretation - S.G., Z.U.Ş., N.C., Ş.E.A., D.K., G.B.; Literature Search - S.G., Z.U.Ş., N.C.; Writing - S.G., Z.U.Ş., N.C., D.K.; Critical Reviews - S.G., Z.U.S.., N.C., Ş.E.A., D.K., G.B.

Conflict of interest statement: The authors declared no conflict of interest. 


\section{REFERENCES}

[1] Vargas-Mendoza N, Madrigal-Santillán E, Morales-González Á, Esquivel-Soto J, Esquivel-Chirino C, García-LunaGonzález-Rubio M, Gayosso-de-Lucio JA, Morales-González JA. Hepatoprotective effect of silymarin. World J Hepatol. 2014; 6(3): 144-149. [CrossRef]

[2] Cengiz M, Kutlu HM, Burukoğlu DD, Ayhancı A. A comparative study on the therapeutic effects of silymarin and silymarin-loaded solid lipid nanoparticles on D-GaIN/TNF-a-induced liver damage in Balb/c mice. Food Chem Toxicol. 2015; 77: 93-100. [CrossRef]

[3] Domitrović R, Jakovac H, Blagojević G. Hepatoprotective activity of berberine is mediated by inhibition of TNF-a, COX-2, and iNOS expression in $\mathrm{CCl}_{4}$-intoxicated mice. Toxicology. 2011; 280: 33-43. [CrossRef]

[4] Anadozie SO, Akinyemi JA, Agunbiade S, Ajiboye BO, Adewale OB. Bryophyllum pinnatum inhibits arginase II activity and prevents oxidative damage occasioned by carbon tetrachloride $\left(\mathrm{CCl}_{4}\right)$ in rats. Biomed Pharmacother. 2018; 101: 8-13. [CrossRef]

[5] Ozay Y, Guzel S, Erdogdu I, Yildirim Z, Pehlivanoglu B, Turk B, Darcan S. Evaluation of the wound healing properties of luteolin ointments on excision and incision wound models in diabetic and non-diabetic rats. Rec Nat Prod. 2018; 12(4): 350-366. [CrossRef]

[6] Fan L, Ma Y, Liu Y, Zheng D, Huang G. Silymarin induces cell cycle arrest and apoptosis in ovarian cancer cells. Eur J Pharmacol. 2014; 743: 79-88. [CrossRef]

[7] Fehér J, Lengyel G. Silymarin in the prevention and treatment of liver diseases and primary liver cancer. Curr Pharm Biotechnol. 2012; 13: 210-217. [CrossRef]

[8] Ghaznavi H, Mehrzadi S, Dormanesh B, Tabatabaei SMTH, Vahedi H, Hosseinzadeh A, Pazoki-Toroudi H, Rashidian A. Comparison of the protective effects of melatonin and silymarin against gentamicin-induced nephrotoxicity in rats. J Evid Based Complementary Altern Med. 2016; 21(4): 49-55. [CrossRef]

[9] Dabak DO, Kocaman N. Effects of silymarin on methotrexate-induced nephrotoxicity in rats. Ren Fail. 2015; 37(4): 734-739. [CrossRef]

[10] Chang JC, Wu YT, Lee WC, Lin LC, Tsai TH. Herb-drug interaction of silymarin or silibinin on the pharmacokinetics of trazodone in rats. Chem Biol Interact. 2009; 182: 227-232. [CrossRef]

[11] Elyasi S, Khalili H, Dashti-Khavidaki S, Mohammadpour A. Vancomycin-induced nephrotoxicity: mechanism, incidence, risk factors and special populations: a literature review. Eur J Clin Pharmacol. 2012; 68(9): 1243-1255. [CrossRef]

[12] Patel N, Joseph C, Corcoran GB, Ray SD. Silymarin modulates doxorubicin-induced oxidative stress, Bcl-xL and p53 expression while preventing apoptotic and necrotic cell death in the liver. Toxicol Appl Pharmacol. 2010; 245: 143152. [CrossRef]

[13] Sozmen M, Devrim AK, Tunca R, Bayezit M, Dag S, Essiz D. Protective effects of silymarin on fumonisin B1-induced hepatotoxicity in mice. J Vet Sci. 2014; 15(1): 51-60. [CrossRef]

[14] Sajedianfard J, Nazifi S, Izadi A, Chahardahcherik M, Honarmad M. Effect of various doses of silymarin on the oxidative stress induced by busulfan administration in the different organs of rats. Turk J Pharm Sci. 2016; 13(2): 233240. [CrossRef]

[15] Kim SH, Lee IC, Baek HS, Shin IS, Moon C, Bae CS, Kim SH, Kim JC, Kim HC. Mechanism for the protective effect of diallyl disulfide against cyclophosphamide acute urotoxicity in rats. Food Chem Toxicol. 2014; 64: 110-118. [CrossRef]

[16] Aghazadeh S, Amini R, Yazdanparast R, Ghaffari SH. Anti-apoptotic and anti-inflammatory effects of Silybum marianum in treatment of experimental steatohepatitis. Exp Toxicol Pathol. 2011; 63: 569-574. [CrossRef]

[17] Elmore S. Apoptosis: a review of programmed cell death. Toxicol Pathol. 2007; 35(4): 495-516. [CrossRef]

[18] Kandemir FM, Yildirim S, Kucukler S, Caglayan C, Mahamadu A, Dortbudak MB. Therapeutic efficacy of zingerone against vancomycin-induced oxidative stress, inflammation, apoptosis and aquaporin 1 permeability in rat kidney. Biomed Pharmacother. 2018; 105: 981-991. [CrossRef]

[19] Wu Y, Zhao D, Zhuang J, Zhang F, Xu C. Caspase-8 and caspase-9 functioned differently at different stages of the cyclic stretch-induced apoptosis in human periodontal ligament cells. PLoS One. 2016; 11(12): e0168268. [CrossRef]

[20] Filippone E, Kraft WK, Farber JL. The nephrotoxicity of vancomycin. Clin Pharmacol Ther. 2017; 102(3): 459-469. [CrossRef]

[21] Gupta A, Biyani M, Khaira A. Vancomycin nephrotoxicity: myths and facts. Neth J Med. 2011; 69(9): $379-383$. 
[22] Sahin M, Cam H, Olgar S, Tunc SE, Arslan C, Uz E, Yilmaz HR. Protective role of erdosteine on vancomycin-induced oxidative stress in rat liver. Mol Cell Biochem. 2006; 291: 155-160. [CrossRef]

[23] El-Adawi H, El-Azhary D, Abd El-Wahab A, El-Shafeey M, Abdel-Mohsen M. Protective effect of milk thistle and grape seed extracts on fumonisin B1 induced hepato- and nephro-toxicity in rats. J Med Plants Res. 2011; 5(27): 63166327. [CrossRef]

[24] Karimi G, Vahabzadeh M, Lari P, Rashedinia M, Moshiri M. Silymarin, a promising pharmacological agent for treatment of diseases. Iran J Basic Med Sci. 2011; 14(4): 308-317.

[25] Chiu FL, Lin JK. Down-regulation of androgen receptor expression by luteolin causes inhibition of cell proliferation and induction of apoptosis in human prostate cancer cells and xenografts. Prostate. 2008; 68: 61-71. [CrossRef]

[26] Bektur NE, Sahin E, Baycu C, Unver G. Protective effects of silymarin against acetaminophen-induced hepatotoxicity and nephrotoxicity in mice. Toxicol Ind Health. 2016; 32: 589-600. [CrossRef]

[27] Choi YH, Cho SS, Simkhada JR, Rahman M.S, Choi YS, Kim CS, Yoo JC. A novel multifunctional peptide oligomer of bacitracin with possible bioindustrial and therapeutic applications from a Korean food-source Bacillus strain. PLoS One. 2017; 12(5): e0176971. [CrossRef]

[28] Manna SK, Mukhopadhyay A, Van NT, Aggarwal BB. Silymarin suppresses TNF-induced activation of NF-kB, c-Jun N-terminal kinase, and apoptosis. J Immunol. 1999; 163: 6800-6809.

[29] Zhang W, Hong R, Tian T. Silymarin's protective effects and possible mechanisms on alcoholic fatty liver for rats. Biomol Ther (Seoul). 2013; 21(4): 264-269. [CrossRef]

[30] Kumas M, Esrefoglu M, Guler EM. Protective effects of silymarin against isotretinoin induced liver and kidney injury in mice. Indian J Exp Biol. 2018; 56: 158-163.

[31] Navidi-Shishaone M, Mohhebi S, Nematbakhsh M, Roozbehani S, Talebi A, Pezeshki Z, Eshraghi-Jazi F, Mazaheri S, Shirdavani S, Gharagozloo M, Moaeidi BA. Co-administration of silymarin and deferoxamine against kidney, liver and heart iron deposition in male iron overload rat model. Int J Prev Med. 2014; 5(1): 110-116.

[32] Nishino Y, Takemura S, Minamiyama Y, Hirohashi K, Tanaka H, Inoue M, Okada S, Kinoshita H. Inhibition of vancomycin-induced nephrotoxicity by targeting superoxide dismutase to renal proximal tubule cells in the rat. Redox Rep. 2002; 7: 317-319. [CrossRef]

[33] Konishi H, Morita Y, Mizumura M, Iga I, Nagai K. Difference in nephrotoxicity of vancomycin administered once daily and twice daily in rats. J Chemother. 2013; 25: 273-278. [CrossRef]

[34] Burukoglu D, Ozer MC, Celik M, Baycu C. The role of satellite cells in crush injury of rat skeleton muscle. Eskişehir Technical University J Sci Technol C-Life Sci Biotechnol. 2013; 3(1): 1-7.

[35] Lowry OH, Rosebrough NJ, Farr AL, Randall RJ. Protein measurement with the folin phenol reagent. J Biol Chem. 1951; 193: 265-275.

This is an open access article which is publicly available on our journal's website under Institutional Repository at http://dspace.marmara.edu.tr. 